\section{Ipsilateral rotational autokeratoplasty: a review}

F Arnalich-Montiel ${ }^{1}$ and JKG Dart ${ }^{1,2}$

\begin{abstract}
Corneal opacity is a major cause of monocular blindness and, after cataract, is also a leading cause of blindness worldwide. Keratoplasty techniques for the treatment of corneal opacities include deep anterior lamellar allokeratoplasty, penetrating allokeratoplasty, penetrating bilateral autokeratoplasty, and ipsilateral rotational autokeratoplasty (IRA). This review describes the indications, technique, and outcomes of IRA. IRA is only indicated for patients with a localised opacity leaving a minimum diameter of 4-5 $\mathrm{mm}$ of

cause of blindness worldwide. The World Health Organisation has estimated that ocular trauma and corneal ulceration may be responsible for 1.5-2.0 million new cases of monocular blindness every year. ${ }^{1}$ The leading cause of blindness in children is corneal opacification caused by a combination of measles, xerophthalmia, and the use of traditional eye medicine. ${ }^{2}$ Many of the corneal scars resulting from these diseases involve the full stromal thickness. Treatment options are the use of contact lenses or surgery using one of the several keratoplasty techniques.
\end{abstract} uninvolved clear cornea. For these few patients in whom the procedure is practicable, the surgery can be planned by manipulating digital images to estimate the trephine size and location and/or by the use of formulas. IRA may not provide either as good spectacle acuity or as good quality of vision as penetrating keratoplasty because of higher astigmatism and a reduced corneal pupillary clear zone, but these disadvantages are often outweighed when the risk of allograft rejection is high, as in paediatric patients and those with vascularised corneas. The main benefits of IRA are the retention of host endothelium, thereby eliminating both the risk of endothelial rejection and the prolonged attrition of endothelial cell numbers that occurs following penetrating keratoplasty, and the reduced requirement for postoperative steroid therapy with its associated complications.

Eye (2009) 23, 1931-1938; doi:10.1038/eye.2008.386; published online 9 January 2009

Keywords: ipsilateral rotational autokeratoplasty; review; indications; techniques; outcomes

\section{Introduction}

Corneal opacity is a leading cause of monocular blindness, and follows cataracts as a leading

\section{Rigid contact lenses}

Rigid contact lenses can provide good acuity, with minimal risk, for patients with scars involving the pupillary zone by eliminating the effect of corneal irregular astigmatism on vision. However, the quality of vision, including contrast sensitivity and glare, may not be improved. If a contact lens service is available, this technique should be tried first as results can be good, ${ }^{3,4}$ and many patients will require contact lenses for optimal vision after keratoplasty anyway.

\section{Keratoplasty techniques}

Keratoplasty techniques include deep anterior lamellar allokeratoplasty, penetrating allokeratoplasty, penetrating bilateral autokeratoplasty, and ipsilateral rotational autokeratoplasty (IRA). Indications for these different techniques vary and may be influenced by the availability of donor material and a contact lens service.

\section{Anterior allogeneic lamellar keratoplasty}

Anterior allogeneic lamellar keratoplasty may

be automated, manual, or deep manual.

Anterior lamellar keratoplasty almost completely avoids the problems of corneal endothelial rejection and late endothelial failure

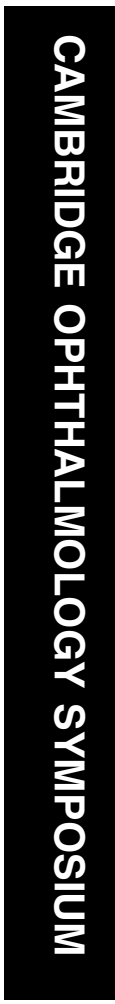

${ }^{1}$ Corneal and External Disease Service, Moorfields Eye Hospital NHS Foundation Trust, London, UK

${ }^{2}$ Department of Pathology, The Institute of Ophthalmology, University College London, London, UK

Correspondence: JKG Dart, Corneal and External Disease Service, Moorfields Eye Hospital, 162 City Road, London EC1V 2PD, UK Tel: + 440207566 2320; Fax: + 4402075662019 . E-mail: j.dart@ ucl.ac.uk

Received: 14 September 2008

Accepted in revised form: 14 September 2008 Published online: 9 January 2009

Presentations: This paper was presented at the Cambridge Ophthalmological Symposium 2008. 
that are associated with penetrating corneal allografts and, as a result, this is the technique of choice for many surgeons for partial thickness scars retaining clear deep stromal tissue. However, the depth of the scar and the opacity of the posterior layers are often difficult to assess clinically before surgery. This is important because deep scars result in the failure of some deep lamellar techniques (eg, big bubble) resulting in the need to convert to a penetrating graft, or increased technical difficulty (eg, Melles technique) together with the inability to determine the presence and opacity of residual deep stromal scar tissue until after the dissection had been completed at which point a decision could be made about whether to proceed with a penetrating or lamellar graft. However, anterior segment ocular coherence tomography (OCT) permits imaging through corneal scar tissue allowing assessment of the thickness of residual clear stroma before surgery, so that these problems can be anticipated.

Penetrating allogenic keratoplasty

Penetrating allogenic keratoplasty has been the procedure of choice for full-thickness corneal opacity. However, endothelial rejection rates of $15-20 \%$ are common, 5,6 and are increased in non-compliant patients and vascularised corneas. ${ }^{5,7-10}$ In addition to rejection, late corneal failure after a successful penetrating allogenic transplant, is anticipated due to the continued loss of donor corneal endothelial cells with time. ${ }^{11}$

Both lamellar and penetrating allogeneic keratoplasty techniques require organ donation. The supply of donor allogenic corneal transplants is limited in countries without an eye banking infrastructure or where cultural considerations prohibit the postmortem removal of any organ from the body. ${ }^{12}$ Alternative techniques to allogenic keratoplasty are bilateral autokeratoplasty and IRA, which eliminate the requirement for both corneal donation and allograft. Both of these techniques minimise the loss of donor endothelial cells resulting from the tissue handling and storage necessitated by eye banking procedures. ${ }^{13}$ Nevertheless, both techniques may result in corneal decompensation. ${ }^{14}$

\section{Bilateral autokeratoplasty}

Bilateral autokeratoplasty is indicated when there is a healthy cornea in an eye with retinal blindness and an opaque cornea in the contralateral eye, which has visual potential. The clear cornea from the eye with retinal blindness is switched with the opaque cornea from the eye with visual potential. ${ }^{15}$

\section{Ipsilateral autokeratoplasty}

Ipsilateral autokeratoplasty is indicated when the extent of the scarring in the affected cornea, and any associated endothelial damage, is limited so that a central opacity can be exchanged for peripheral clear cornea. In the 1960s, techniques were described for rectangular ${ }^{16}$ and 'Figure $8^{\prime}$ grafts ${ }^{17}$ that minimised the size of the corneal incision to achieve transposition of clear peripheral with opaque central corneal tissue. However, these techniques have been rarely reported, probably because the wound apposition is more difficult with rectangular grafts, and modified instruments are required for 'Figure 8 ' grafts. In the subsequent decades, the necessary transposition has been achieved by eccentric trephination - the technique of IRA. ${ }^{18}$ This review will describe the aims, indications, surgical techniques, and outcomes for this procedure. Because the procedure is relatively infrequently performed, the data available are based on a few reports of case series ${ }^{12-14,18-23}$ with $27^{14}$ or fewer cases, often with incomplete data.

\section{Aims}

To achieve an adequate clear corneal pupillary zone, with minimal astigmatism, and an improved cosmetic result (by placing the scar under the upper lid where possible), without precipitating corneal decompensation.

\section{Indications}

IRA has been associated with higher corneal astigmatism and lower visual acuity when compared with homologous penetrating keratoplasty. ${ }^{20}$ However, appropriate patient selection may minimise these problems. The following criteria are suggested:

\section{Type of opacity}

Non-progressive corneal scars following blunt and penetrating corneal trauma, postinfectious keratitis scars, congenital opacities, and chemical injuries ${ }^{12,14,21}$ in progressive cases of idiopathic or postherpetic (zoster and simplex) lipid keratopathy. ${ }^{23}$

\section{Size of opacity}

Assuming a normal mean corneal diameter of $11 \mathrm{~mm}$ (vertical)-11.5 mm (horizontal), there should be at least $4^{21,23}$ or $5 \mathrm{~mm}^{14}$ of clear cornea in the peripheral cornea (although one author has suggested a minimum of $3 \mathrm{~mm}^{12}$ ). This clear corneal diameter is required to obtain a clear entrance pupil of $3 \mathrm{~mm}$, free of suture track scars, when employed with maximum decentration of the trephine to the limbus. The optimal clear pupillary zone is probably $5 \mathrm{~mm}$ to minimise glare, ${ }^{18}$ but this can only be achieved with scars that occupy less than half of the mean corneal diameter. This is because an additional 
$1.5 \mathrm{~mm}$ of clear cornea is needed to allow for a suture bite length of $0.75 \mathrm{~mm}$, and scars of such a small size may not require surgery.

\section{Endothelial cell count}

This technique may fail when endothelial cell counts are below $1000 \mathrm{~mm}^{2}$. However, in practical terms, meaningful endothelial cell counts are difficult or impossible to obtain, so that the reliance is often placed on the quality of the specular reflex and the presence of normal pachymetry in the peripheral clear cornea.

\section{Patients with high risk of rejection}

Densely vascularised corneal leukomas ${ }^{23}$, or surgery in children because of their higher risk of rejection. ${ }^{14}$

\section{Reduced availability of donor material}

The technique is useful in countries where donor material is scarce and expensive, or donation is forbidden. ${ }^{12}$

\section{Surgical technique}

The technique is identical in principle to that of conventional penetrating keratoplasty with the exception that host cornea is eccentrically cut and then rotated, instead of being replaced with a donor cornea, before suturing. Any additional anterior segment procedures (separation of anterior synechiae, pupilloplasty, cataract extraction, and primary or secondary lens implantation) may be carried out. ${ }^{12,14,20}$ The details of cutting the cornea, suturing, and ancillary techniques will not be described here other than to say that interrupted sutures are recommended because of the more rapid loosening of sutures that occurs with sutures placed into the anterior sclera; this may lead to premature loosening of a continuous suture.

The size and position of the host corneal trephine and position of the rotated scar are critical in achieving the key aims of the procedure (a clear central optical zone with minimum astigmatism and a good cosmetic result). A number of different methods are described to help predict the feasibility of the procedure and optimise the results.

\section{Determining the size and location of the trephination}

Several papers describe the results without identifying a technique other than surgeon's judgment. ${ }^{12,14,19}$ However, several methods have been described to aid judgment, and these can be summarised as surgical guidelines, mathematical formulas of varying simplicity, and the use of digital image manipulation.

\section{Surgical guidelines}

One publication recommends that a minimum of $3 \mathrm{~mm}$ of clear peripheral cornea and trephine size of $6-7 \mathrm{~mm}$ will normally be adequate - these guidelines could result in placement of the edge of the clear cornea in the geometric centre of the cornea leaving the patient little better off it at all. ${ }^{12}$

The other publication recommends: ${ }^{21}$

(1) Choosing cases having a minimum diameter of clear cornea of $4 \mathrm{~mm}$ and utilising a trephine size of 8.00 $9.00 \mathrm{~mm}$

(2) Decentration of the trephine so that the peripheral edge of the corneal button is very close to the limbus.

(3) Placing the central edge of the corneal button at least $3 \mathrm{~mm}$ from the visual axis (how this is ascertained is not stated; for an $11.5 \mathrm{~mm}$ cornea, this will require a 9.0$\mathrm{mm}$ trephine if the peripheral edge is at the limbus).

(4) If possible rotate the opacity under the upper lid (to optimise the cosmetic result).

Table 1 Formulas for calculating trephine size in ipsilateral rotational autografting

\begin{tabular}{|c|c|c|}
\hline Authors & Formula & Required measurements \\
\hline $\begin{array}{l}\text { Bourne and } \\
\text { Brubaker }{ }^{18}\end{array}$ & $\mathrm{Dt}=1.5 \times \mathrm{Dcl}+\mathrm{e}^{\mathrm{a}}$ & $\begin{array}{l}\text { 1. Diameter of the } \\
\text { largest circle of } \\
\text { clear cornea } \\
\text { 2. The shortest } \\
\text { distance from the } \\
\text { geometric centre of } \\
\text { the cornea to the } \\
\text { junction of the } \\
\text { circle of clear } \\
\text { cornea and the } \\
\text { opacity }\end{array}$ \\
\hline $\begin{array}{l}\text { Jonas } \\
\text { et } a l^{20}\end{array}$ & $\mathrm{Dt}=0.75 \times \mathrm{Dcd}-0.5 \times \mathrm{e}$ & $\begin{array}{l}\text { 1. Overall corneal } \\
\text { diameter in the axis } \\
\text { of the greatest } \\
\text { maximum extent of } \\
\text { scarring } \\
\text { 2. The shortest } \\
\text { distance from the } \\
\text { geometric centre of } \\
\text { the cornea to the } \\
\text { junction of the } \\
\text { circle of clear } \\
\text { cornea and the } \\
\text { opacity }\end{array}$ \\
\hline
\end{tabular}

$\mathrm{Dt}=$ trephine diameter; $\mathrm{Dcd}=$ overall diameter of the cornea in the axis of the largest diameter of clear cornea; $\mathrm{Dcl}=$ diameter of the largest area of clear cornea; $\mathrm{e}=$ the shortest distance from the geometric centre of the cornea to the junction of the circle of clear cornea and the opacity. $\mathrm{e}^{\mathrm{a}}$ is positive if the scar involves the centre of the cornea and negative if the corneal centre is in the largest circle of clear cornea. 
These guidelines have been formalised by Rao and Lam $^{24}$ who suggest some simple intraoperative measurements to aid the sizing and centration of the autograft.

\section{Mathematical formulas}

The two most useful are described in Table 1. The most frequently quoted method ${ }^{13,14,23}$ is that of Bourne and Brubaker, ${ }^{18}$ which utilises a simple geometric method for determining the maximum area of clear postoperative
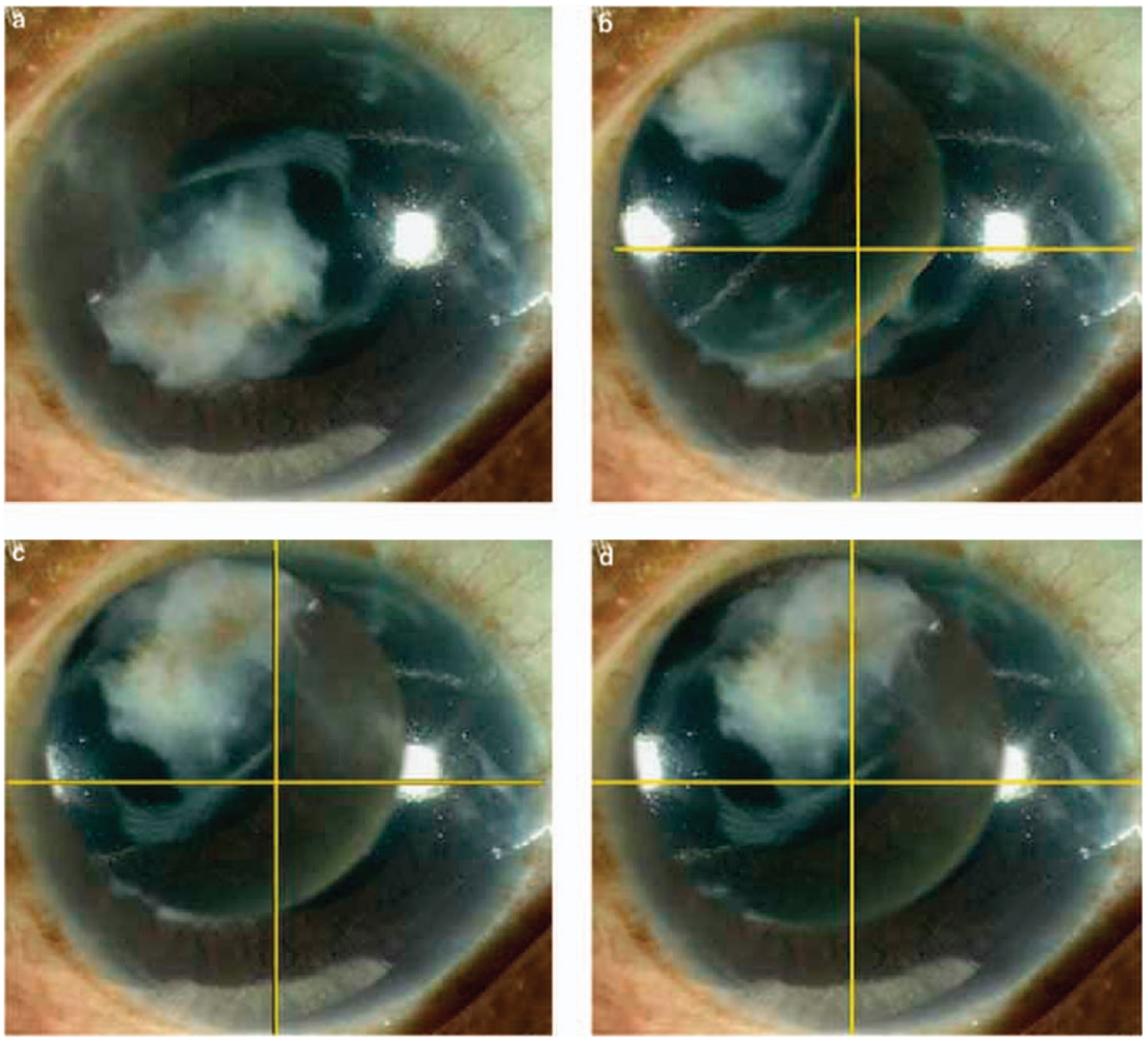

Figure 1 Examples of digital simulations of a trauma case for planning the feasibility of ipsilateral rotational autokeratoplasty (IRA). This example has only $3.0 \mathrm{~mm}$ of clear cornea and is not a good candidate for IRA because of the limited postoperative clear pupillary zone. The best centration of the clear cornea over the geometric axis of the cornea is using a 7.25-mm trephine for this case. (a) Digital image of the cornea adjusted to $11.5 \mathrm{~mm}$ overall diameter. (b) Simulation of a trephine size of $7.25 \mathrm{~mm}$. This is closest to the result of the Bourne and Brubacker formula (see Table 1) where: Dt (diameter of the trephine) $=(1.5 \times 3.0)+1.7=7.2 \mathrm{~mm}$. (c) Simulation of a trephine size of $7.75 \mathrm{~mm}$. This is closest to the result of the Jonas formula (see Table 1) where: Dt (diameter of the trephine $)=(0.75 \times 11.5)+(0.5 \times 1.7)=7.8 \mathrm{~mm}$. (d) Simulation of a trephine size of $8.0 \mathrm{~mm}$.

central cornea and the trephine size to achieve this result. Placement of the trephine is at the limbus. Examples of this in use are shown in their study.

When the site of the pupil cannot be identified, this method is a good guide to the location of the trephine. However, Harris ${ }^{25}$ implies that substituting the centre of the pupil, when this can be located, instead of the geometric centre of the cornea in Bourne and Brubaker's ${ }^{18}$ calculations will give a better estimate of the centre of the entrance pupil of the eye and improve the visual outcome.

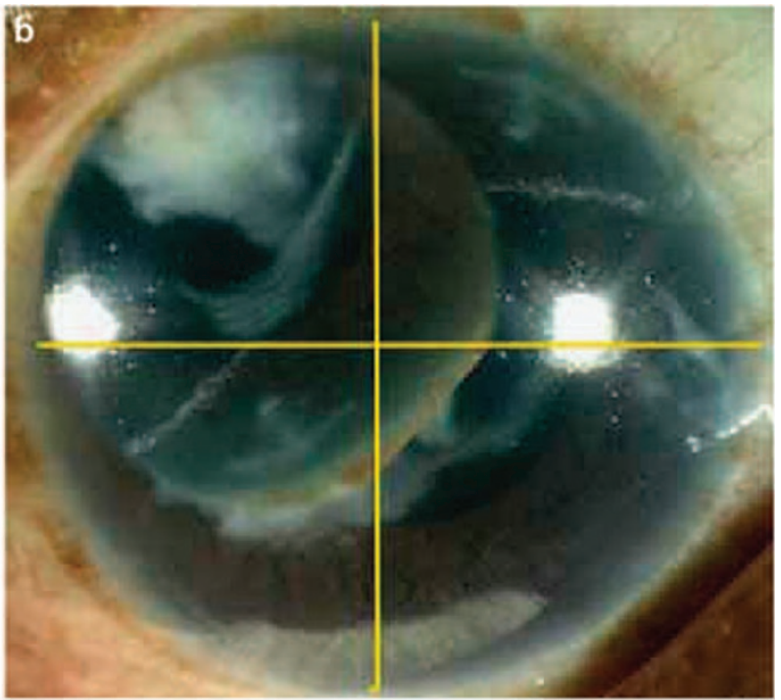


The other easy to use formula by Jonas et al, ${ }^{20}$ also shown in Table 1, utilises a trephine size of 0.75 of the overall corneal diameter, when the scar lies at the geometric centre of the cornea, and adjusts this according to the extent of the scar. Both the Jonas et $a l^{20}$ and Bourne and Brubaker ${ }^{18}$ formulas give similar results with the Jonas et $a l^{20}$ formula giving a slightly larger trephine size. When these sizes are rounded up to the nearest $0.25 \mathrm{~mm}$, there is often no difference between the estimates given by both formulas. Figure 1 shows a case in which the trephine sizes differ by $0.25 \mathrm{~mm}$ for each formula; in this instance, the Bourne and Brubacker ${ }^{18}$ formula gives the optimal estimate based on the simulation by digital image manipulation (see below).

A third formula is designed to optimise the rotation of a linear corneal scar away from the entrance pupil. ${ }^{26}$ It makes assumptions that are arguable ${ }^{25}$ has limited applications, and it is probably redundant.

Table 2 Summary of literature giving outcomes for ipsilateral rotational autokeratoplasty

\begin{tabular}{|c|c|c|c|c|c|c|}
\hline Authors & $\begin{array}{l}\text { Demographics } \\
\text { a. Total } \mathrm{n} \\
\text { b. Vision } \\
\text { assessed } \mathrm{n} \\
\text { c. Age range yrs }\end{array}$ & Visual outcomes & $\begin{array}{l}\text { Astigmatism outcomes } \\
\text { a. Number } \\
\text { b. Mean and range in } \\
\text { dioptres } \\
\text { c. Suture status }\end{array}$ & Failures & $\begin{array}{l}\text { Follow-up } \\
\text { (months) }\end{array}$ & $\begin{array}{l}\text { Other data } \\
\text { a. Cause and sizes of opacity } \\
\text { b. Additional surgery (pupilloplasty, } \\
\text { release of synechiae, and cataract } \\
\text { surgery) } \\
\text { c. Endothelial cell loss and visual } \\
\text { outcomes compared with allografts }\end{array}$ \\
\hline $\begin{array}{l}\text { Groden and } \\
\text { Arentsen }{ }^{19}\end{array}$ & $\begin{array}{l}\text { a. } 10 \\
\text { b. } 9 \\
\text { c. } 3-77\end{array}$ & $\begin{array}{l}\text { Nine improved } \\
\text { Seven were } \\
6 / 15-6 / 9\end{array}$ & $\begin{array}{l}\text { a. } 5 \\
\text { b. Mean 5.0; range =1-9 } \\
\text { c. Suture status uncertain }\end{array}$ & Nil & Not stated & $\begin{array}{l}\text { a. } \text { Trauma }=7 \text {, interstitial } \\
\text { keratitis }=2, \text { postpterygium } \\
\text { surgery }=1 \\
\text { b. Additional surgery }=4 / 10\end{array}$ \\
\hline $\begin{array}{l}\text { McDonnell } \\
\text { and Falcon }{ }^{21}\end{array}$ & $\begin{array}{l}\text { a. } 16 \\
\text { b. } 13 \\
\text { c. } 3-63\end{array}$ & $\begin{array}{l}13 \text { improved } \\
\text { Eight were } 6 / 12 \\
\text { or better }\end{array}$ & $\begin{array}{l}\text { a. } 6 \\
\text { b. Mean 2.0; range }=0-4 \\
\text { c. Suture status uncertain }\end{array}$ & Nil & $\begin{array}{l}\text { Mean } 27 \\
\text { Range }=2-83\end{array}$ & $\begin{array}{l}\text { a. } \text { Trauma }=14 \text { and trachoma }=2 \\
\text { b. Additional surgery }=15 / 16\end{array}$ \\
\hline Sah et $a l^{23}$ & $\begin{array}{l}\text { a. } 4 \\
\text { b. All } \\
\text { c. } 13-53\end{array}$ & $\begin{array}{l}\text { All improved } \\
20 / 25-20 / 200\end{array}$ & $\begin{array}{l}\text { a. } 4 \\
\text { b. Range }=2.5-4.5 \\
\text { c. Suture status uncertain }\end{array}$ & $\begin{array}{l}\text { One progressive } \\
\text { cataract } \\
\text { One suture track } \\
\text { vascularisation }\end{array}$ & Range $=11-24$ & $\begin{array}{l}\text { a. All lipid keratopathy: } \\
\text { postkeratitis }=2, \text { postpterygium } \\
\text { excision }=1 \text {, unknown }=1 \\
\text { b. None stated }\end{array}$ \\
\hline Verma et $a l^{12}$ & $\begin{array}{l}\text { a. } 17 \\
\text { b. All } \\
\text { c. } 5-42\end{array}$ & $\begin{array}{l}\text { All improved } \\
\text { from preop HMs } \\
\text { to } 5 / 60-6 / 9 \\
\text { Eight were } 6 / 12 \\
\text { or better }\end{array}$ & $\begin{array}{l}\text { a. Not reported } \\
\text { b. One case with high } \\
\text { irregular astigmatism } \\
\text { limiting vision to } 5 / 60 \\
\text { c. Suture status uncertain }\end{array}$ & $\begin{array}{l}\text { One traumatic } \\
\text { wound rupture } \\
\text { successfully } \\
\text { repaired } \\
\text { One residual } \\
\text { opacity in } \\
\text { pupillary zone }\end{array}$ & Uncertain & $\begin{array}{l}\text { a. Causes not stated, opacity } \\
\text { diameter } 4-7.5 \mathrm{~mm} \\
\text { b. Additional surgery }=6\end{array}$ \\
\hline Murthy et $a l^{14}$ & $\begin{array}{l}\text { a. } 27 \\
\text { b. } 20 \\
\text { c. } 0.25-60\end{array}$ & $\begin{array}{l}13 \text { were } 20 / 80 \\
\text { or more } \\
\text { Seven were } 20 / 40 \\
\text { or more }\end{array}$ & $\begin{array}{l}\text { a. } 17 \\
\text { b. Mean } 4.25 \text {; range }=1-9 \\
\text { c. Suture status uncertain }\end{array}$ & $\begin{array}{l}\text { Two } \\
\text { decompensated } \\
\text { grafts } \\
\text { One glaucoma } \\
\text { resulting in graft } \\
\text { failure }\end{array}$ & $\begin{array}{l}\text { Mean } 12 \\
\text { (five lost to } \\
\text { follow-up) }\end{array}$ & $\begin{array}{l}\text { a. Trauma }=12 \text {, } \\
\text { postkeratitis }=8 \text {, chemical } \\
\text { injury }=4 \text {, congenital }=2 \text {, and } \\
\text { unknown }=1 \\
\text { b. Additional surgery }=12 / 27\end{array}$ \\
\hline $\begin{array}{l}\text { Bertelmann } \\
\text { et } a l^{13}\end{array}$ & $\begin{array}{l}\text { a. } 7 \\
\text { b. All } \\
\text { c. } 20-85\end{array}$ & $\begin{array}{l}\text { Mean } \\
\text { improvement } \\
3.5 \text { lines } \\
20 / 200-20 / 25\end{array}$ & $\begin{array}{l}\text { a. } 7 \\
\text { b. Mean } 4.75 \pm 1.5 \mathrm{D}(\mathrm{SD}) \\
\text { c. Sutures removed in } \\
\text { patients having } \\
\text { astigmatism }>4 \mathrm{D} \text { at } 1 \\
\text { year }\end{array}$ & $\begin{array}{l}\text { One corneal } \\
\text { decompensation } \\
\text { One retinal } \\
\text { detachment }\end{array}$ & Mean 39 & $\begin{array}{l}\text { a. Trauma }=4 \text {, postkeratitis }=3 \\
\text { b. Additional surgery }=3 \\
\text { c. Endothelial cell loss compared } \\
\text { with } 293 \text { allografts at } 1 \text {-year } \\
\text { postop showed mean cell loss } \\
\text { (SD) of } 15 \%( \pm 7.2 \%) \text { in } \\
\text { autografts vs } 40 \%( \pm 21.3 \% \text { in } \\
\text { allografts) }\end{array}$ \\
\hline
\end{tabular}

HMs $=$ hand movements; postop $=$ postoperative; preop $=$ preoperative. 


\section{Digital image manipulation}

An early publication describes the use a digitised corneal image and a computer programme to optimise the centre of trephination and the optimal trephine diameter, and seems to have no advantages over the previously described methods. ${ }^{27}$ A more recent publication describes the use of widely available digital image manipulation software (Photoshop 5.0, Adobe) to plan the size, location, and rotation of the graft to provide optimal centration of the clear cornea over the pupil, and the scar position to optimise the cosmetic result. Appendix 1 describes a method for this in more detail using Adobe Photoshop 7.0, adopting the use of the digital ruler, and resizing the image to facilitate the measurement of the diameters of the cornea, the scar, and the maximum clear zone. Figure 1 shows the results of digital manipulation in one case using a selection of simulated trephine sizes two of which have been calculated by the formulas described above.

\section{Outcomes and complications}

These are summarised in Table 1 for seven case series, 12-14,19-21,23 which include 160 cases in whom the visual acuity outcomes have been reported for 79 cases and the astigmatism outcomes for 48 cases. These case series vary in the quality of the data they present, but they provide a substantial number of cases for the assessment of the value of the procedure.

\section{Astigmatism}

The study by Jonas $e t a l^{20}$ is the only one to have compared visual outcomes with that of a nonrandomised control group of penetrating allografts, and found significantly higher astigmatism in the nine patients having autografts. However, the reported astigmatism is higher in this study than in any of the other reported series, which have reported astigmatism levels in the same order as those for penetrating keratoplasty. Therefore, it is possible, but not proven, that astigmatism outcomes are higher in this group. Potential reasons for the increased astigmatism, if this truly occurs, are the eccentric trephination, disparity of corneal thickness between the peripheral clear cornea and the central scarred cornea into which it is sutured, and the proximity of one edge of the trephination to the corneal pupillary zone. ${ }^{20}$

\section{Visual acuity}

Visual acuity results are reported in Table 1. From the five studies in which the results of individual cases are reported, ${ }^{12,14,19,21,23} 31 / 64(48 \%)$ were 6/12 or better, although it is not clear whether this was unaided with spectacles or with contact lenses.

\section{Transplant survival and endothelial cell loss}

In Table 1, there were 4/160 decompensated corneas, one of which followed uncontrolled glaucoma. These corneal decompensations are likely to have been related to loss of endothelium, over and above the loss resulting from the disease causing the opacity that were related to the surgery. Long-term results are unknown, but Bertelmann et $\mathrm{al}^{13}$ has shown that mean endothelial cell loss was $15 \%$ in rotational autografts compared with $40 \%$ in homografts at 1 year, such that the survival of autografts can be expected to compare well with the failure rates of $20 \%$ after 10 years due to the continued attrition of endothelial cells and the high rate of transplant rejection in penetrating corneal homografts. ${ }^{11,28}$

\section{Other complications}

These are summarised in Table 2 and are similar to those expected in any series of penetrating corneal surgery.

\section{Conclusions}

IRA probably does not provide as good best-corrected visual acuity as penetrating keratoplasty and may result in higher astigmatism. However, there are three benefits, which outweigh these disadvantages for many patients, particularly when the risk of allograft rejection may be higher than normal as in paediatric keratoplasty and when the cornea is vascularised as in many patients following trauma:

1. The retention of host endothelium therefore avoiding endothelial rejection.

2. The stability of the endothelial cell population in autografts unlike that of allografts, which is expected to lead to transplant failure after 20-30 years. ${ }^{11}$

3. The reduced need for compliance with the use of postoperative steroid drops to prevent rejection and the associated complications of glaucoma, cataract, and infection. ${ }^{29-31}$

A limited visual outcome may well outweigh the potential short-term benefits of a penetrating allograft in patients who are suitable for ipsilateral rotational autografts.

In this context, an autograft should probably be attempted when some improvement in vision can be expected, particularly in patients whose second eye is normal and for whom some improvement in vision, at lower risk, is acceptable. 
Unfortunately, few patients are suitable for this procedure. Only patients with a minimum diameter of uninvolved cornea of $4-5 \mathrm{~mm}$ are suitable (those with only $2-3 \mathrm{~mm}$ may get minimal improvement, but this will be limited by the likelihood of suboptimal centration of the clear cornea with the line of sight, ${ }^{32}$ in addition to the effect of the additional scarring, resulting from suture track scars on the clarity of the remaining clear cornea). In such patients with extensive scars, the failure rate may be higher due to endothelial cell loss resulting from the original trauma and further loss as a complication of necessary additional procedures required at the time of surgery; the effective endothelial cell count is usually impossible to assess with precision before surgery because of poor visualisation of endothelium through scar tissue and difficulty obtaining peripheral endothelial cell counts in residual clear cornea.

For those patients in whom the procedure is practicable, planning of the procedure is by manipulating digital images, as described in Appendix 1, using an estimate of the trephine size and postoperative pupillary clear zone derived from the techniques of Bourne and Brubaker ${ }^{18}$ or Jonas et al. ${ }^{20}$

\section{References}

1 Whitcher JP, Srinivasan M, Upadhyay MP. Corneal blindness: a global perspective. Bull World Health Organ 2001; 79: 214-221.

2 Steinkuller PG, Du L, Gilbert C, Foster A, Collins ML, Coats DK. Childhood blindness. J AAPOS 1999; 3: 26-32.

3 Kanpolat A, Ciftci OU. The use of rigid gas permeable contact lenses in scarred corneas. CLAO J 1995; 21: 64-66.

4 Kok JH, Smulders F, van Mil C. Fitting of aspheric high gaspermeable rigid contact lenses to scarred corneas. Am J Ophthalmol 1991; 112: 191-194.

5 Alldredge OC, Krachmer JH. Clinical types of corneal transplant rejection. Their manifestations, frequency, preoperative correlates, and treatment. Arch Ophthalmol 1981; 99: 599-604.

6 Claesson M, Armitage WJ, Fagerholm P, Stenevi U. Visual outcome in corneal grafts: a preliminary analysis of the Swedish Corneal Transplant Register. Br J Ophthalmol 2002 86: $174-180$.

7 Maguire MG, Stark WJ, Gottsch JD, Stulting RD, Sugar A, Fink NE et al. Risk factors for corneal graft failure and rejection in the collaborative corneal transplantation studies. Collaborative Corneal Transplantation Studies Research Group. Ophthalmology 1994; 101: 1536-1547.

8 Price MO, Thompson Jr RW, Price Jr FW. Risk factors for various causes of failure in initial corneal grafts. Arch Ophthalmol 2003; 121: 1087-1092.

9 Sit M, Weisbrod DJ, Naor J, Slomovic AR. Corneal graft outcome study. Cornea 2001; 20: 129-133.

10 Thompson Jr RW, Price MO, Bowers PJ, Price Jr FW. Longterm graft survival after penetrating keratoplasty. Ophthalmology 2003; 110: 1396-1402.
11 Armitage WJ, Dick AD, Bourne WM. Predicting endothelial cell loss and long-term corneal graft survival. Invest Ophthalmol Vis Sci 2003; 44: 3326-3331.

12 Verma N, Melengas S, Garap JA. Ipsilateral rotational autokeratoplasty for the management of corneal opacities. Aust N Z J Ophthalmol 1999; 27: 21-25.

13 Bertelmann E, Hartmann C, Scherer M, Rieck P. Outcome of rotational keratoplasty: comparison of endothelial cell loss in autografts $v$ s allografts. Arch Ophthalmol 2004; 122: 1437-1440.

14 Murthy S, Bansal AK, Sridhar MS, Rao GN. Ipsilateral rotational autokeratoplasty: an alternative to penetrating keratoplasty in nonprogressive central corneal scars. Cornea 2001; 20: 455-457.

15 Price Jr FW, Hanna SI. Bilateral penetrating autokeratoplasty. J Refract Surg 1995; 11: 494-496.

16 Mortada A. Rectangular autogenous lamellar keratoplasty. Br J Ophthalmol 1963; 47: 232-236.

17 Wilson RS. 'Figure 8' ipsilateral autokeratoplasty. A modification using standard corneal trephines. Arch Ophthalmol 1976; 94: 121-122.

18 Bourne WM, Brubaker RF. A method for ipsilateral rotational autokeratoplasty. Ophthalmology 1978; 85: 1312-1316.

19 Groden LR, Arentsen JJ. Ipsilateral rotating autokeratoplasty. Ann Ophthalmol 1983; 15: 899-901.

20 Jonas JB, Rank RM, Budde WM. Autologous ipsilateral rotating penetrating keratoplasty. Am J Ophthalmol 2001; 131: 427-430.

21 McDonnell PJ, Falcon MG. Rotational autokeratoplasty. Eye 1989; 3(Part 5): 576-580.

22 Robinson LP. Keratoplasty following anterior segment trauma. Aust J Ophthalmol 1981; 9: 59-62.

23 Sah WJ, Myoung YW, Hahn TW, Kim JH. Rotational autokeratoplasty in advanced lipid keratopathy. Ophthalmic Surg Lasers 1997; 28: 1020-1024.

24 Rao SK, Lam DS. Calculating graft size and position in rotational corneal autografting: a simplified approach. Indian J Ophthalmol 2008; 56: 228-230.

25 Harris Jr DJ. Centration of clear zone over the pupil is the best strategy for rotational autografts. Arch Ophthalmol 2007; 125: 992-993.

26 Afshari NA, Duncan SM, Tanhehco TY, Azar DT. Optimal size and location for corneal rotational autografts: a simplified mathematical model. Arch Ophthalmol 2006; 124: 410-413.

27 Karpouzas I, Pouliquen YJ. Computerized method for rotational autokeratoplasty. Cornea 1991; 10: 369-371.

28 Ing JJ, Ing HH, Nelson LR, Hodge DO, Bourne WM. Tenyear postoperative results of penetrating keratoplasty. Ophthalmology 1998; 105: 1855-1865.

29 Donshik PC, Cavanaugh HD, Boruchoff SA, Dohlman CH. Posterior subcapsular cataracts induced by topical corticosteroids following keratoplasty for keratoconus. Ann Ophthalmol 1981; 13: 29-32.

30 Greenlee EC, Kwon YH. Graft failure: III. Glaucoma escalation after penetrating keratoplasty. Int Ophthalmol 2008; 28: 191-207.

31 Sharif KW, Casey TA. Penetrating keratoplasty for keratoconus: complications and long-term success. Br J Ophthalmol 1991; 75: 142-146.

32 Uozato H, Guyton DL. Centering corneal surgical procedures. Am J Ophthalmol 1987; 103: 264-275. 


\section{Appendix 1}

Using adobe photoshop 7.0 to manipulate corneal images for ipsilateral rotational autokeratoplasty

1. File $>$ Open $>$ the digital image for manipulation

2. Crop image to include the cornea only

3. Setup scale

3.1. View $>$ rulers

3.2. Double click on rulers to change to $\mathrm{mm}$ scale

3.3. Drag origin of ruler (top left) to left hand side of cornea

4. Resize the image to scale

4.1. Image $>$ Image size alter document width so that horizontal diameter of the cornea matches its measured diameter (with callipers on slit lamp) or white to white of $11.5 \mathrm{~mm}$ (normal corneal diameter). If the image size is too small, then multiply by a factor of 10 , that is, adjust to $115 \mathrm{~mm}$.

5. Select Window $>$ Info to view the size of selections

6. Create markers to identify the geometric centre of the cornea

6.1. L click on rulers and drag into position using Info dialog box to ensure the position is correct
6.2. To fine adjust ruler, click and hold Ctrl to move

7. Open Window $>$ layers dialogue box

7.1. Create new layer (click arrow in top right of dialogue box to create new layer).

7.2. Ensure background layer is not locked (otherwise selection cannot me made)

7.3. Name new layer with the size of the graft

7.4. Select background layer (unlocked) before selecting trephine size

8. Select elliptical marquee tool (to simulate trephine size)

8.1. Left click, and then hold Shift to constrain shape to a circle (trephine size)

8.2. Choose size of the circle using the Window Info dialogue box

8.3. Move the selected area into position with the cursors

8.4. Copy the selection (Edit $>$ Copy)

8.5. Select the new layer

8.6. Paste into the new layer (Edit $>$ Paste)

9. To move the new graft around to assess effect:

9.1. Edit $>$ Transform $>$ Rotate

9.2. When the position is optimal File $>$ Save as $>$ new size of graft 